\title{
GENERALIZED STEFFENSEN'S INEQUALITY
}

\section{ASFAND FAHAD, JOSIP PEČARIĆ AND MARJAN PRALJAK}

Abstract. We give a generalization of Steffensen's inequality by extending the results of Pečarić [4] and Rabier [5]. We make use of the $n$-order Taylor expansion of a composition of functions and Faà di Bruno's formula for higher order derivatives of the composition.

Mathematics subject classification (2010): 26D10, 26D15.

Keywords and phrases: Steffensen's inequality, Faà di Bruno's formula.

\section{REFERENCES}

[1] A. ČIŽMeŠIJA AND J. PeČARIĆ, Some new generalizations of inequalities of Hardy and LevinCochran-Lee, Bull. Aust. Math. Soc. 63, 1 (2001), 105-113.

[2] E. Hewitt And K. Stromberg, Real and abstract analysis, 3rd edition, Springer, New York, 1975.

[3] W. P. Johnson, The Curious History of Faà di Bruno's Formula, Amer. Math. Monthly 109 (2002), 217-234.

[4] J. PeČARIĆ, Connections among some inequalities of Gauss, Steffensen and Ostrowski, Southeast Asian Bull. Math. 13, 2 (1989), 89-91.

[5] P. RABIER, Steffensen's inequality and $L^{1}-L^{\infty}$ estimates of weighted integrals, Proc. Amer. Math. Soc. 140, 2 (2012), 665-675.

[6] J. F. STEFFENSEN, On certain inequalities between mean values, and their application to actuarial problems, Skand. Aktuarietidskr. 1 (1918), 82-97. 